\title{
Unusual Coordination of Tetraphenylborate to Silver(I): Synthesis and X-ray Crystal Structure of the Complex $N, N^{\prime}$-bis[3-(2-nitrophenyl)allylidene]ethane-1,2- diamine(tetraphenylborato)silver(I)
}

\author{
Saeed Dehghanpour, ${ }^{*, a}$ Ali Mahmoudi ${ }^{b}$ and Ramin Hadjikhani ${ }^{b}$ \\ ${ }^{a}$ Department of Chemistry, Alzahra University, 1993891176 Tehran, Iran \\ ${ }^{b}$ Faculty of Science, Islamic Azad University, Karaj Branch, Karaj, Iran
}

\begin{abstract}
O complexo $N, N$ '-bis[3-(2-nitrofenil)alilideno]etano-1,2-diamino(tetrafenilborato)prata(I), $\left[\mathrm{Ag}\left(\mathrm{nca}_{2} \mathrm{en}\right)\left(\mathrm{BPh}_{4}\right)\right]$, foi sintetizado e caracterizado por análise elementar e por espectroscopias de $\mathrm{RMN}$ de ${ }^{1} \mathrm{H}$, de absorção no infravermelho e UV-vis. Sua estrutura cristalina e molecular foi determinada por difratometria de raios $\mathrm{X}$ (monocristal). O centro de prata(I) no complexo está em um ambiente tetraédrico distorcido e faz ligações covalentes com os dois átomos de nitrogênio da base de Schiff e com dois átomos de carbono do tetrafenilborato. No complexo, o tetrafenilborato apresenta um comportamento não-usual, agindo como um ligante bidentado.
\end{abstract}

The complex $N, N$ '-bis[3-(2-nitrophenyl)allylidene]ethane-1,2-diamine(tetraphenylborato) silver(I), $\left[\mathrm{Ag}\left(\mathrm{nca}_{2} \mathrm{en}\right)\left(\mathrm{BPh}_{4}\right)\right]$, has been synthesized and characterized by $\mathrm{CHN}$ analyses and ${ }^{1} \mathrm{H}-\mathrm{NMR}$, IR and UV-vis spectroscopies. Its crystal and molecular structure was determined by $\mathrm{X}$-ray diffractometry from single-crystal data. The coordination geometry about silver(I) is best described as a distorted tetrahedron. The Ag center is covalently bonded to two $\mathrm{N}$ atoms of the Schiff base and two $\mathrm{C}$ atoms of tetraphenylborate. In the complex, tetraphenylborate shows an unusual behavior and acts as a bidentate ligand.

Keywords: silver(I) complex, diimine ligand, nitrocinnamaldehyde, tetraphenylborate, crystal structure

\section{Introduction}

Many notable recent advances in the chemistry of silver(I) complexes have been achieved through the use of diimine ligands. These complexes have drawn special attention because of their applications as reagents in organic and inorganic synthesis, ${ }^{1}$ in photography or electrochemical silver plating, ${ }^{2}$ and as free radical scavengers in industrial processes. ${ }^{3-6}$ Cation- $\pi$ interactions between metal ions and polycyclic aromatic hydrocarbons have also received considerable attention in the synthesis of coordination compounds, mainly due to the possibility of introducing a variety of useful electric and electrochemical properties and of giving rise to novel molecular architectures.

Cinnamaldehyde and its substituted derivatives react with ethylenediamine to give a range of diimine compounds;

*e-mail: dehganpour_farasha@yahoo.com a small number of such bis(cinnamaldehyde)ethylenediimine ligands have been used to give complexes with transition metals..$^{7-9}$ Although reports on $\left[\mathrm{Ag}^{\mathrm{I}}(\mathrm{NN})_{2}\right]^{+}(\mathrm{NN}$ is a diimine obtained from cinnamaldehyde derivatives and ethylenediamine) and $\left[\mathrm{Ag}^{\mathrm{I}}-\pi-\mathrm{Ar}\right]^{+}$complexes are numerous, limited work on silver(I) complexes with mixed ligands, $[\mathrm{Ag}(\mathrm{NN})(\pi-\mathrm{Ar})]^{+}$, has been reported. ${ }^{10-19}$ In the present work, we report the synthesis and characterization of the new complex $\left[\mathrm{Ag}\left(\right.\right.$ nca $\left.\left._{2} \mathrm{en}\right)\left(\mathrm{BPh}_{4}\right)\right](\mathbf{1})$, as well as its molecular structure determined from single crystal X-ray diffraction analysis.

\section{Experimental}

All chemicals were reagent grade and used as received. Solvents were purified by literature methods. ${ }^{20} N, N^{\prime}$-bis[3(2-nitrophenyl)allylidene] ethane-1,2-diamine, nca 2 en, was prepared according to literature procedures. ${ }^{21}$ Elemental 
analyses were performed by using a Heraeus CHN-ORAPID elemental analyzer. Infrared spectra were recorded on a Bruker Tensor 27 instrument. Electronic absorption spectra were recorded on a JASCO V-570 spectrophotometer. NMR spectra were obtained on a BRUKER AVANCE DRX500 (500 MHz, $11.75 \mathrm{~T}$ ) spectrometer. Hydrogen chemical shifts are reported in parts per million (ppm) relative to $\mathrm{Me}_{4} \mathrm{Si}$ as internal standard.

\section{Synthesis of N,N'-bis[3-(2-nitrophenyl)allylidene]ethane-} 1,2-diamine(tetraphenylborato)silver(I), 1

To a stirring solution of $N, N$ '-bis[3-(2-nitrophenyl) allylidene]ethane-1,2-diamine (nca 2 en, $378 \mathrm{mg}, 1 \mathrm{mmol}$ ) in $5 \mathrm{~mL}$ acetonitrile, silver nitrate $(169 \mathrm{mg}, 1 \mathrm{mmol}$ in 5 $\mathrm{mL}$ acetonitrile) and sodium tetraphenylborate $(342 \mathrm{mg}$, $1 \mathrm{mmol}$ in $5 \mathrm{~mL}$ acetonitrile) were added. After stirring for $10 \mathrm{~min}$, the volume of the solvent was reduced under vacuum to about $4 \mathrm{~mL}$. The diffusion of diethyl ether vapor into the concentrated solution gave light yellow crystals, which were filtered off, washed with a mixture of diethyl ether-acetonitrile $(9: 1 \mathrm{v} / \mathrm{v})$ and dried under vacuum. Anal. calcd. for $\mathrm{C}_{44} \mathrm{H}_{38} \mathrm{AgBN}_{4} \mathrm{O}_{4}: \mathrm{C}, 65.61 ; \mathrm{H}, 4.76 ; \mathrm{N}, 6.96 \%$. Found: C, 65.63; H, 4.75; N, $6.98 \%$. IR (KBr pellets, v/ $\left.\mathrm{cm}^{-1}\right): 1610(\mathrm{C}=\mathrm{N}) .{ }^{1} \mathrm{H}-\mathrm{NMR}\left(500 \mathrm{MHz}, \mathrm{CDCl}_{3}\right): \delta 4.02(\mathrm{~s}$,

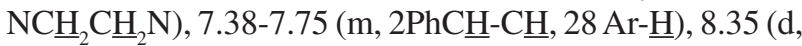
$\left.{ }^{3} J(\mathrm{H}-\mathrm{H}) 9 \mathrm{~Hz}, 2 \mathrm{CHC} \underline{\mathrm{H}}=\mathrm{N}\right)$.

\section{$X$-ray crystallography}

Diffraction data for $\mathbf{1}$ were collected on a STOEIPDSII diffractometer using graphite-monochromated Mo- $\mathrm{K}_{\alpha}$ radiation $(\lambda=0.71073 \AA$ ). Data were collected and integrated using the Stoe X-AREA software package. ${ }^{22}$ A numerical absorption correction was applied using X-RED and X-SHAPE softwares. ${ }^{23}$ The structure was solved by direct methods (SHELXS-97). ${ }^{33}$ The structure refinement was performed by a full-matrix least-squares method against $F^{2}$ (SHELXL-97). ${ }^{24}$ All non-H atoms were refined anisotropically and all $\mathrm{H}$ atoms were inserted in calculated positions.

\section{Results and Discussion}

The IR spectrum of the proligand exhibits the characteristic band of the imine group, which appears at $1605 \mathrm{~cm}^{-1}$. This band is shifted to lower frequencies in the IR spectra of the corresponding complexes due to the coordination of the imine nitrogen. ${ }^{25}$

Since no d-d transitions are expected for a $\mathrm{d}^{10}$ complex, the UV-Vis bands are assigned to metal to ligand charge transfer (MLCT) or ligand-centered $\pi \rightarrow \pi^{*}$ transitions. ${ }^{26}$ The absorption spectrum of $\left[\mathrm{Ag}\left(\mathrm{nca}_{2} \mathrm{en}\right)\left(\mathrm{BPh}_{4}\right)\right](\mathbf{1})$ in chloroform features a clear shoulder at $320 \mathrm{~nm}(\log \varepsilon=3.73)$. Additional absorption bands are also observed in the spectra of $\mathbf{1}$ in chloroform in the UV region $\left[\lambda_{\max }=280 \mathrm{~nm}(\log \varepsilon=4.61)\right]$. The intensity of these bands is consistent with ligand-centered $\pi \rightarrow \pi^{*}$ and/or charge-transfer transitions.

${ }^{1} \mathrm{H}$ NMR peak assignments, based on the splitting of resonance signals, spin coupling constants, and the literature, are presented in the experimental section. These assignments are in accordance with the molecular structure determined by X-ray crystal structure analysis. The ${ }^{1} \mathrm{H}$ resonances of the coordinated nca en are clearly observed in complex 1; however, the aromatic $\mathrm{H}$ atoms of the coordinated $\mathrm{Ph}_{4} \mathrm{~B}$ overlap to some extent with those of the phenyl $\mathrm{H}$ atoms of nca $_{2}$ en. Aside from the aromatic$\mathrm{H}$ atoms, which appear at 7.38-7.45 ppm, the two imine hydrogens appear as a doublet at $c a .8 .35 \mathrm{ppm}$ in $\mathbf{1}$. The shift of the iminic hydrogens to high frequency relative to the proligand can be attributed to the deshielding effect resulting from coordination. The singlet at $4.02 \mathrm{ppm}$ in $\mathbf{1}$ is assigned to the $\mathrm{H}$ atoms of the $\mathrm{CH}_{2} \mathrm{CH}_{2}$ group. In principle, geometrical isomers are possible with respect to the $\mathrm{C}=\mathrm{N}$ bond. However, the appearance of only one signal for each type of proton in $\mathrm{CDCl}_{3}$ solution indicates that the symmetry of the molecule is retained in solution, and only one isomer is present.

A view of complex 1, including the atom numbering scheme, is illustrated in Figure 1. Crystallographic data are summarized in Table 1 and selected bond distances and angles are listed in Table 2. Compound $\mathbf{1}$ crystallizes with two molecules per asymmetric unit, probably due to some small conformational differences (1A, 1B). The coordination environment around the metal ion in this complex is pseudotetrahedral, with a large angular distortion arising from the low intraligand $\mathrm{N}-\mathrm{Ag}-\mathrm{N}$ chelate angle $\left[75.64(13)^{\circ}\right.$ in $1 \mathrm{~A}$ and $76.44(13)^{\circ}$ in $1 \mathrm{~B}$ ] and the intraligand $\mathrm{C}-\mathrm{Ag}-\mathrm{C}$ chelate angle $\left[99.71(16)^{\circ}\right.$ in $1 \mathrm{~A}$ and $98.86(15)^{\circ}$ in 1B]. The other angles around the Ag center are larger than those of a non-distorted tetrahedral complex. The $\mathrm{Ag}-\mathrm{N}$ bond distances [2.322(4) and 2.293(4) $\mathrm{A}$ in $1 \mathrm{~A}$ and 2.331(4) and 2.324(4) $\AA$ in 1B] are similar to those found in other $\mathrm{Ag}$ pseudotetrahedral complexes. ${ }^{27-29} \mathrm{In}$ the complex, the average $\mathrm{Ag}-\mathrm{C}$ bond distance is $2.48 \AA$, which is comparable to those reported for $\mathrm{Ag}-\mathrm{C}$ bond distances for coordinated polyenes. ${ }^{30-33}$ The coordination environment around the boron atom is approximately tetrahedral, since the average of six angles involving $\mathrm{B}$ is $109.5^{\circ}$, although the angles $\mathrm{C} 21-\mathrm{B} 1-\mathrm{C} 27$ in $1 \mathrm{~A}$ and $\mathrm{C} 65-\mathrm{B} 1-\mathrm{C} 71$ in $1 \mathrm{~B}$ have values of $103.5(3)^{\circ}$ and $103.9(3)^{\circ}$ respectively. The $\mathrm{Ag}$ center is approximately perpendicular to the coordinated phenyl rings of tetraphenylborate (for example, the angles 
Table 1. Crystal data and single crystal X-ray diffraction refinement details for compound $\mathbf{1}$

\begin{tabular}{|c|c|}
\hline Formula & $\mathrm{C}_{44} \mathrm{H}_{38} \mathrm{AgBN}_{4} \mathrm{O}_{4}$ \\
\hline Formula weight & 804.96 \\
\hline Crystal system & Triclinic \\
\hline Space group & P-1 \\
\hline$a(\AA)$ & $12.698(3)$ \\
\hline$b(\AA)$ & $13.610(3)$ \\
\hline$c(\AA)$ & $22.491(5)$ \\
\hline$\alpha\left({ }^{\circ}\right)$ & $89.68(3)$ \\
\hline$\beta\left(^{\circ}\right)$ & $87.82(3)$ \\
\hline$\gamma\left(\left(^{\circ}\right)\right.$ & $88.88(3)$ \\
\hline $\mathrm{V}\left(\mathrm{A}^{3}\right)$ & 3883.3(13) \\
\hline $\mathrm{Z}$ & 4 \\
\hline Density $\left(\mathrm{g} \mathrm{cm}^{-3}\right)$ & 1.378 \\
\hline$\mu\left(\mathrm{Mo}-\mathrm{K}_{\alpha}\right)\left(\mathrm{mm}^{-1}\right)$ & 0.57 \\
\hline$F(000)$ & 1656 \\
\hline \multicolumn{2}{|c|}{ Data collection } \\
\hline Temperature (K) & 293(2) \\
\hline$\theta \min -\max$ & $1.50-27.12$ \\
\hline Dataset $[\mathrm{h}, \mathrm{k}, \mathrm{l}]$ & $-16 / 15,-17 / 17,-28 / 28$ \\
\hline Tot., Uniq. Data, R(int) & $29700,15388,0.0430$ \\
\hline Observed data & $>2 \sigma(\mathrm{I})$ \\
\hline \multicolumn{2}{|c|}{ Refinement } \\
\hline No. reflections, No. parameters & 15388,973 \\
\hline $\mathrm{R} 1, \mathrm{R} 2$ & $0.0699,0.0951$ \\
\hline wR1, wR2 & $0.1635,0.1779$ \\
\hline Goodness-of-fit & 1.114 \\
\hline Max. and Av. Shift/Error & $0.006,0.000$ \\
\hline Min, Max. Resd. Dens. (e/A $\left.{ }^{3}\right)$ & $0.88,-0.85$ \\
\hline
\end{tabular}

Ag1-C22-C23 in $1 \mathrm{~A}$ and Ag2-C72-C73 in 1B have values of $91.9(4)^{\circ}$ and $90.0(3)^{\circ}$, respectively).

Despite the fact that the $\mathrm{N}$-donor atoms are $\mathrm{sp}^{2}$-hybridized, the chelate ring is significantly puckered in this complex, and some strain in the chelate ring is suggested by deviation from the $120^{\circ}$ angle about the $\mathrm{N}$-atom, as for $\mathrm{C} 9-\mathrm{N} 2-\mathrm{C} 10\left[119.7(4)^{\circ}\right]$, Ag1-N2-C9 [132.0(3) $)^{\circ}$, and Ag1-N2-C10 [108.2(3) $\left.{ }^{\circ}\right]$ in 1A, and C55-N7-C56 [120.1(4) $\left.{ }^{\circ}\right], \mathrm{Ag} 2-\mathrm{N} 7-\mathrm{C} 55$ [107.7(3) $\left.{ }^{\circ}\right]$ and Ag2-N7-C56 [132.1(3) $\left.{ }^{\circ}\right]$ in 1B.

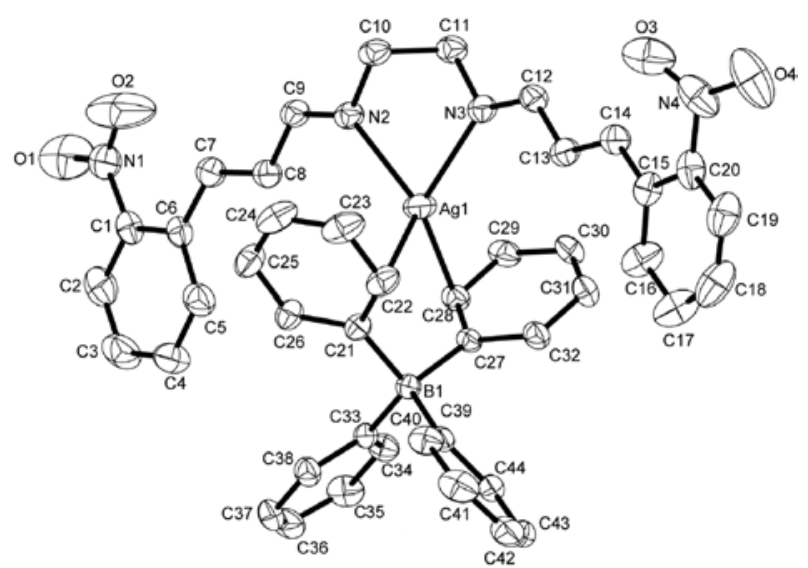

Figure 1. ORTEP view of the crystal structure of $\left[\mathrm{Ag}\left(\mathrm{nca}_{2} \mathrm{en}\right)\left(\mathrm{BPh}_{4}\right)\right](\mathbf{1 A})$, with the atom labeling scheme. Thermal ellipsoids are drawn at the $50 \%$ probability level. Hydrogen atoms are omitted for clarity.

\section{Conclusions}

A novel silver(I) complex has been synthesized, containing $N, N$ '-bis[3-(2-nitrophenyl)allylidene]ethane-

Table 2. Selected bond lengths $[\AA]$ and bond angles $\left[^{\circ}\right]$ for $\mathbf{1}$

\begin{tabular}{|c|c|c|c|}
\hline \multicolumn{2}{|c|}{$1 \mathrm{~A}$} & \multicolumn{2}{|c|}{$1 \mathrm{~B}$} \\
\hline $\mathrm{Ag} 1-\mathrm{N} 2$ & $2.322(4)$ & Ag2-N7 & $2.331(4)$ \\
\hline $\mathrm{Ag} 1-\mathrm{N} 3$ & $2.293(4)$ & $\mathrm{Ag} 2-\mathrm{N} 6$ & $2.324(4)$ \\
\hline $\mathrm{Ag} 1-\mathrm{C} 22$ & $2.503(5)$ & $\mathrm{Ag} 2-\mathrm{C} 66$ & 2.497 (5) \\
\hline $\mathrm{Ag} 1-\mathrm{C} 28$ & $2.479(5)$ & $\mathrm{Ag} 2-\mathrm{C} 72$ & $2.443(4)$ \\
\hline $\mathrm{N} 2-\mathrm{Ag} 1-\mathrm{N} 3$ & $75.64(13)$ & N6-Ag2-N7 & $76.44(14)$ \\
\hline $\mathrm{C} 22-\mathrm{Ag} 1-\mathrm{C} 28$ & $99.71(16)$ & $\mathrm{C} 66-\mathrm{Ag} 2-\mathrm{C} 72$ & $98.86(15)$ \\
\hline $\mathrm{N} 2-\mathrm{Ag} 1-\mathrm{C} 22$ & $119.22(16)$ & N6-Ag2-C66 & $117.10(15)$ \\
\hline $\mathrm{N} 2-\mathrm{Ag} 1-\mathrm{C} 28$ & $120.94(14)$ & $\mathrm{N} 6-\mathrm{Ag} 2-\mathrm{C} 72$ & $125.38(15)$ \\
\hline $\mathrm{N} 3-\mathrm{Ag} 1-\mathrm{C} 22$ & $125.73(14)$ & $\mathrm{N} 7-\mathrm{Ag} 2-\mathrm{C} 66$ & $118.82(16)$ \\
\hline $\mathrm{N} 3-\mathrm{Ag} 1-\mathrm{C} 28$ & $125.73(14)$ & $\mathrm{N} 7-\mathrm{Ag} 2-\mathrm{C} 72$ & $121.47(14)$ \\
\hline $\mathrm{Ag} 1-\mathrm{C} 22-\mathrm{C} 23$ & $91.9(4)$ & $\mathrm{Ag} 2-\mathrm{C} 72-\mathrm{C} 73$ & $90.0(3)$ \\
\hline $\mathrm{Ag} 1-\mathrm{C} 28-\mathrm{C} 29$ & $91.1(3)$ & $\mathrm{Ag} 2-\mathrm{C} 66-\mathrm{C} 67$ & $90.6(4)$ \\
\hline $\mathrm{Ag} 1-\mathrm{N} 2-\mathrm{C} 9$ & $132.0(3)$ & $\mathrm{Ag} 2-\mathrm{N} 7-\mathrm{C} 55$ & 107.7(3) \\
\hline $\mathrm{Ag} 1-\mathrm{N} 2-\mathrm{C} 10$ & $108.2(3)$ & $\mathrm{Ag} 2-\mathrm{N} 7-\mathrm{C} 56$ & 132.1(3) \\
\hline $\mathrm{C} 9-\mathrm{N} 2-\mathrm{C} 10$ & $119.7(4)$ & $\mathrm{C} 55-\mathrm{N} 7-\mathrm{C} 56$ & $120.1(4)$ \\
\hline $\mathrm{C} 21-\mathrm{B} 1-\mathrm{C} 27$ & $103.5(3)$ & $\mathrm{C} 65-\mathrm{B} 2-\mathrm{C} 71$ & $103.9(3)$ \\
\hline $\mathrm{C} 39-\mathrm{B} 1-\mathrm{C} 27$ & $110.3(3)$ & $\mathrm{C} 77-\mathrm{B} 2-\mathrm{C} 71$ & $114.2(3)$ \\
\hline $\mathrm{C} 39-\mathrm{B} 1-\mathrm{C} 33$ & $106.4(3)$ & $\mathrm{C} 77-\mathrm{B} 2-\mathrm{C} 83$ & $106.2(3)$ \\
\hline
\end{tabular}


1,2-diamine and tetraphenylborate ligands. The structure determination of the complex shows a discrete molecular structure and a distorted tetrahedral geometry around the silver atom. A major finding of the present work is that the tetraphenylborate shows an unusual behavior and acts as a bidentate ligand.

\section{Supplementary Information}

Crystallographic data (excluding structure factors) for the structure (1) reported in this paper have been deposited with the Cambridge Crystallographic Data Center, CCDC No. 616197. Copy of the data can be obtained free of charge on application to CCDC, 12 Union Road, Cambridge CB2 1EZ, UK (fax: +44 1223 336033; e-mail: deposit@ccdc.cam.ac.uk or http://www.ccdc.cam.ac.uk). ${ }^{1} \mathrm{H}$ NMR data of compound $\mathbf{1}$ are available free of charge at http://jbcs.sbq.org.br, as PDF file.

\section{References}

1. Mehrotra, R.; Bohra, R.; Metal Carboxylates, Academic Press: London, 1983.

2. Xue, G.; Dong, J.; Sun, Y.; Langmuir, 1994, 10, 1477.

3. Berners-Price, S. J.; Sadler, P. J.; Coord. Chem. Rev. 1990, 15, 1.

4. Henry, P. M.; Adv. Organomet. Chem. 1975, 13, 363.

5. Cohen, H.; Meyerstein, D.; Inorg. Chem. 1986, 25, 1505.

6. Goldstein, S.; Czapski, G.; Cohen, H.; Meyerstein, D.; Inorg. Chem. 1992, 31, 2439.

7. Amirnasr, M.; Kickelbick, G., Dehghanpour, S.; Helv. Chim. Acta, 2006, 89, 274.

8. Dehghanpour, S.; Mahmoudkhani, A. H. Amirnasr, M.; Struct. Chem. 2006, 17, 255.

9. Meghdadi, S.; Amirnasr, M.; Schenk, K. J.; Dehghanpour, S.; Helv. Chim. Acta, 2002, 85, 2807.

10. Munakata, M.; Wu, L. P.; Ning, G. L.; Coord. Chem. Rev. 2000, 198, 171.

11. Porter, L. C.; Polam, J. R.; Mahmoud, J.; Organometallics 1994, 13, 2092.

12. Suravajjala, S.; Polam, J. R.; Porter, L. C.; Organometallics 1994, 13,37

13. Munakata, M.; Wu, L. P.; Kuroda-Sowa, T.; Adv. Inorg. Chem. 1999, 46, 173 .

14. Munakata, M.; Ning, G. L.; Suenaga, Y.; Kuroda-Sowa, T.; Maekawa, M.; Ohta, T.; Angew. Chem., Int. Ed. 2000, 39, 4555.

15. Cingolani, A.; Effendy, Marchetti, F.; Pettinari, C.; Skelton, B. W.; White, A. H.; J. Chem. Soc., Dalton Trans. 1999, 4047.
16. Bowmaker, G. A.; Effendy, Hanna, J. V.; Healy, P. C.; Reid, J. C.; Rickard, C. E. F.; White, A. H.; J. Chem. Soc., Dalton Trans. 2000, 753 .

17. Effendy, Lobbia, G. G.; Pellei, M.; Pettinari, C.; Santini, C.; Skelton, B. W.; White, A. H.; J. Chem. Soc., Dalton Trans. 2000, 2123.

18. Hannon, M. J.; Painting, C. L.; Alcock, N. W.; Chem. Commun. 1999, 2023.

19. Bowyer, P. K.; Porter, K. A.; Rae, A. D.; Willis, A. C.; Wild, S. B.; Chem. Commun. 1998, 1153.

20. Perrin, D. D.; Armarego, W. L.; Perrin, D. R.; Purification of Laboratory Chemicals, $2^{\text {nd }}$ ed., Pergamon: New York, 1990.

21. Dehghanpour, S.; Kempe, R.; Balireddi, S.; Fotouhi, L.; Tabasi, F.; Mojahed, F.; Salek, S.; Z. Anorg. Allg. Chem. 2006, 632, 2321.

22. Stoe \& Cie, $X-R E D$, version 1.28b, Program for Data Reduction and Absorption Correction, Stoe \& Cie GmbH, Darmstadt, Germany, 2005.

23. Stoe \& Cie, X-SHAPE, version 2.05: Program for Crystal Optimization for Numerical Absorption Correction, Stoe \& Cie GmbH, Darmstadt, Germany, 2004.

24. Sheldrick, G. M.; SHELX97. Program for Crystal Structure Solution and Refinement, University of Göttingen, Germany, 1997.

25. Nakamoto, K.; Infrared and Raman Spectra of Inorganic and Coordination Complexes; $4^{\text {th }}$ ed., John Wiley \& Sons: USA, 1992.

26. Lever, A. B. P.; Inorganic Electronic Spectroscopy; $2^{\text {nd }}$ ed., Elsevier: Amsterdam, 1984, p. 496.

27. Amirnasr, M.; Welter, R.; Khalaji, A. D.; Acta Cryst. E, 2005, $61, \mathrm{~m} 1452$.

28. Richmond, T. G.; Kelson, E. P.; Arif, A. M.; J. Am. Chem. Soc. 1988, 110, 2334.

29. Rarig Jr, R. S.; Zubieta, J.; Inorg. Chim. Acta 2001, 319, 235.

30. Munakata, M.; Wu, L.P. ; Kuroda-Sowa, T.; Maekawa, M.; Suenaga, Y.; Ning, G. L.; Kojima, T.; J. Am. Chem. Soc. 1998, 120,8610 .

31. Zhong, J. C.; Munakata, M.; Kuroda-Sowa, T.; Maekawa, M.; Suenaga, Y.; Konaka, H.; Inorg. Chem. 2001, 40, 3191.

32. Liu, S. Q.; Kuroda-Sowa, T.; Konaka, H.; Suenaga, Y.; Maekawa, M.; Mizutani, T.; Ning, G. L.; Munakata, M.; Inorg. Chem. 2005, 44, 1031.

33. Ning, G. L.; Munakata, M.; Wu, L. P.; Maekawa, M.; Suenaga, Y.; Kuroda-Sowa, T.; Sugimoto, K.; Inorg. Chem. 1999, 38, 5668.

Received: May 22, 2007 Web Release Date: February 7, 2008 
Unusual Coordination of Tetraphenylborate to Silver(I): Synthesis and X-ray Crystal Structure of the Complex $N, N^{\prime}$-bis[3-(2-nitrophenyl)allylidene]ethane-1,2diamine(tetraphenylborato)silver(I)

Saeed Dehghanpour, ${ }^{*, a}$ Ali Mahmoudi $i^{b}$ and Ramin Hadjikhani ${ }^{b}$

${ }^{a}$ Department of Chemistry, Alzahra University, 1993891176 Tehran, Iran

${ }^{b}$ Faculty of Science, Islamic Azad University, Karaj Branch, Karaj, Iran
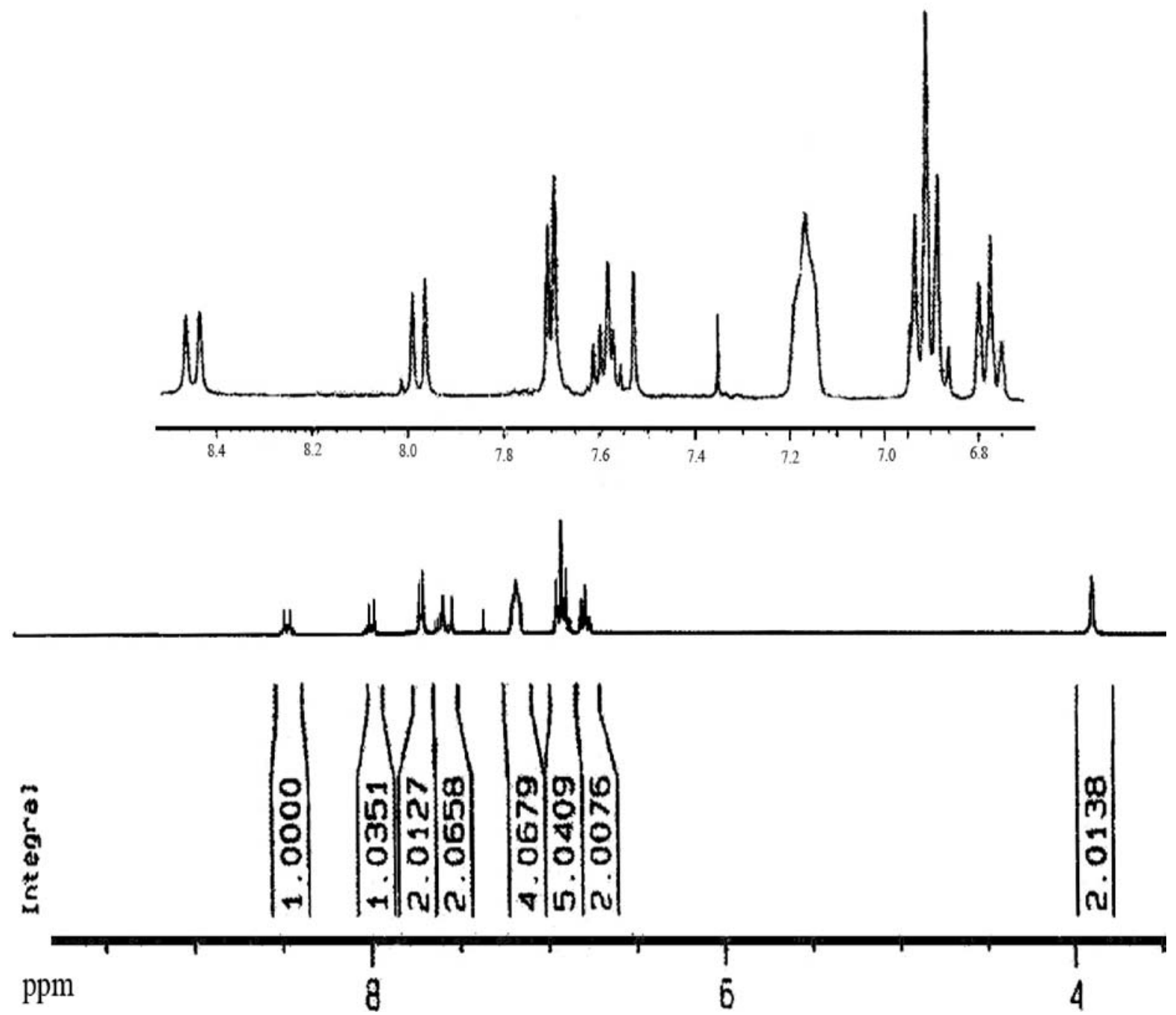

Figure S1. ${ }^{1} \mathrm{H}$ NMR data for compound 1 in $\mathrm{CDCl}_{3}(500 \mathrm{MHz}, 11.75 \mathrm{~T})$.

*e-mail: dehganpour_farasha@yahoo.com 